\title{
Studia
}

SYNCHRONICZNE I DIACHRONICZNE ASPEKTY BADAŃ POLSZCZYZNY

www.wnus.edu.pl/sj | DOI: 10.18276/sj.2017.16-19 | 299-302

\author{
BOGDAN WALCZAK
}

Akademia im. Jakuba z Paradyża w Gorzowie Wlkp.

\section{Agnieszka Piela, Pozorna tożsamość. Polskie tradycjonalizmy z semantycznym archaizmem, Wydawnictwo Uniwersytetu Śląskiego, Katowice 2016, ss. 200}

Nakładem Wydawnictwa Uniwersytetu Śląskiego ukazała się ważna i interesująca monografia z zakresu historycznej frazeologii - książka Agnieszki Pieli Pozorna tożsamość. Polskie tradycjonalizmy z semantycznym archaizmem. W moim przekonaniu trzeba ją uznać za dużej miary osiągnięcie badawcze. O jej wartości stanowią - moim zdaniem - przede wszystkim następujące aspekty, względy i okoliczności:

1) Wybór tematu. Rozprawa sytuuje się w obszarze historycznej (prymarnie, choć faktycznie także współczesnej) frazeologii polskiej (sądzę, że autorka traktuje diachronicznie dynamicznie rozumianą współczesność językową jako ostatnią fazę historii języka), a tymczasem historyczna frazeologia to teren relatywnie słabo dotąd rozpoznany przez badaczy, czego zresztą pełną świadomość (potwierdzoną licznymi stwierdzeniami i przytoczeniami, których już tutaj nie mogę cytować) ma sama autorka odwołująca się w tej kwestii do opinii na ten temat Mariana Kucały i Wojciecha Chlebdy.

2) Solidna podstawa źródłowo-materiałowa, choć w zasadzie ograniczona do źródeł natury leksykograficznej. Trzeba jednak w tym miejscu przyznać, że autorka ma pełną świadomość zarówno zalet, jak i słabości źródeł leksykograficznych (s. 14-15). Ostatecznie, co można w tym wypadku bez zastrzeżeń zaakceptować, wybrała słowniki (zarówno słowniki języka ogólnego, historyczne i współczesne, jak i słowniki frazeologiczne, paremiologiczne, a nawet gwarowe i etymologiczne) jako podstawę źródłowo-materiałową swojej rozprawy, opierając się na opiniach Magdaleny Pastuchowej i Witolda Doroszewskiego, który 
uważał, że słownik jest źródłem wszelkiej wiedzy o języku. W rozdziale analitycznym (s. 60-162) autorka opisuje 90 archaizmów semantycznych jako składników dzisiejszych związków wyrazowych, których uwzględnia oczywiście więcej, gdyż ,[...] jeden element archaiczny może być składnikiem kilku różnych jednostek wyrazowych” (s. 62).

3) Samoistna wartość naukowa (i dydaktyczna, do wyzyskania w dydaktyce na szczeblu magisterskim i doktoranckim) dwu pierwszych rozdziałów (s. 19-59), z których pierwszy traktuje o archaizmach, a drugi - o tradycjonalizmach. O ile pierwszy zawiera uporządkowaną i sproblematyzowaną refleksję na temat rozumienia (w literaturze naukowej) pojęcia archaizmu (choć trudno dociec, dlaczego autorka uważa, że archaiczne formy fleksyjne oczyma i rękoma występują dziś t y $1 \mathrm{k}$ o w zwrotach widzieć coś oczyma duszy i siedzieć z założonymi rękoma (s. 33) - choć kategoryczność tego twierdzenia osłabia w przypisie 58; w istocie oczyma jest dziś recesywnym obocznikiem formy oczami, a rękoma - formy ręka$m i$ i obie mogą być używane w różnych kontekstach, podobnie jak na przykład forma $w$ ręku jest recesywnym obocznikiem formy $w$ ręce - jakkolwiek nigdy formy $w$ rękach, co by było bardziej zrozumiałe i naturalne, bo recesywne formy liczby podwójnej zyskują przecież wartość liczby mnogiej, por. ręce; podobnie trudno dociec, dlaczego awans czy zwiąek nie stanowią obecnie samodzielnych jednostek języka (s. 34), to drugi, jeszcze bardziej nowatorski, traktuje o pojęciu (i terminie) tradycjonalizmu. Jakkolwiek potrzebę tego pojęcia i terminu już dawno widziały Danuta Buttler, Teresa Iglikowska, Halina Kurkowska i Halina Satkiewicz, ich próby jego upowszechnienia zakończyły się niepowodzeniem - można więc zasadnie stwierdzić, że zasługa wprowadzenia do obiegu naukowego terminu tradycjonalizm przypada Agnieszce Pieli. Autorka definiuje tradycjonalizm następująco: ,[...] jest to funkcjonująca we współczesnej polszczyźnie konstrukcja wyrazowa (frazeologizm, przysłowie, zestawienie, termin), mieszcząca w swoim składzie jakikolwiek archaiczny element języka, będący pozostałością po wcześniejszych etapach rozwojowych polszczyzny (np. archaizm fonetyczny, fleksyjny, leksykalny czy semantyczny)" (s. 47).

Spośród najważniejszych tez i ustaleń części wstępnej szczególną uwagę chciałbym zwrócić na dwa. Pierwsze ma charakter ogólny i jest nim zaprezentowana przez śląską badaczkę jej własna, autorska typologia tradycjonalizmów (s. 47-59), drugie natomiast ma charakter szczegółowy. Chodzi tu o to, że Agnieszka Piela Słownik języka polskiego pod redakcją Witolda Doroszewskiego traktuje jako słownik historyczny (s. 11-12). Jest to w moim przekonaniu postępowanie ze wszech miar słuszne - sam też uważam (i dałem temu wyraz), że dzieje polskiego słownictwa obrazują, jako wielkie słowniki typu filologicznego: Słownik staropolski, Słownik polszczyzny XVI wieku, Słownik języka polskiego XVII i 1. połowy XVIII wieku oraz właśnie (w okresie od połowy XVIII do połowy XX wieku) Słownik języka polskiego pod red. Doroszewskiego.

4) Budzące uznanie zaplecze erudycyjne pracy. Wykaz literatury przedmiotu (s. 183191), w którym nie dostrzegam żadnych istotnych luk, obejmuje bez mała 170 pozycji (dokładnie 169), z czego więcej niż jedną trzecią (gdyż 57) stanowią książki, czasem wielotomowe. Godzi się też zauważyć, że choć brak w tym wykazie pozycji obcojęzycznych, 
autorka wyzyskała w polskich przekładach dzieła tak wybitnych uczonych i filozofów jak Bergson, Ong, Sartre czy Wittgenstein. Można więc zasadnie stwierdzić, że rozprawa Agnieszki Pieli jest gruntownie osadzona w literaturze naukowej o charakterze globalnym. Ta obszerna literatura, umiejętnie wyzyskana przez autorkę, jest wyraźnie obecna w jej rozprawie jako wieloraki kontekst naukowy jej własnych tez i konstatacji, stanowiąc zarazem o gruntowności jej książki i jej zakorzenieniu w złożonej problematyce badawczej.

5) Bogactwo analiz i interpretacji, skoncentrowanych przede wszystkim w najobszerniejszym (s. 60-162) rozdziale, zatytułowanym Tradycjonalizmy z unikatem semantycznym w zasobach współczesnej polszczyzny (rozdział ma postać słownika złożonego z 90 artykułów hasłowych - od ambit do żywiec).

6) Zwracająca uwagę czytelnika dociekliwość (czasem iście detektywistyczna) autorki w tropieniu tego, co w dzisiejszej polszczyźnie jest pozostałością po dawnych stanach języka. Nie jest to bynajmniej sprawa łatwa, gdyż, jak słusznie twierdzi sama autorka: „Do tego typu konstrukcji niezwykle trudno dotrzeć, trudno je «wyłowić» z zasobów frazeologicznych polszczyzny. Współczesne słowniki nie podają prawdziwej ich genezy, w żaden sposób nie są one też w leksykonach wyszczególniane (brak opatrzeń dawnego sensu kwalifikacją: archaiczny). Wobec tego nigdy nie można mieć pewności, że baza materiałowa jest kompletna" (s. 16). W powyższym cytacie autorka mówi o zasobach frazeologicznych, ale równie trudno „wyłowić” (by się posłużyć sformułowaniem autorki) tradycjonalizmy z archaizmem semantycznym z zasobu przysłów, zestawień czy terminów - por. choćby bieg wsteczny, derywacja wsteczna czy lusterko wsteczne). Trudno tu jednak nie zauważyć, że ta detektywistyczna dociekliwość jest w jakimś stopniu skutkiem przynależności autorki do śląskiej szkoły językoznawstwa historycznego, w której obrębie ma - w obszarze poszukiwania pomostów łączących polszczyznę historyczną i współczesną - tak wybitne poprzedniczki jak Krystyna Kleszczowa, Magdalena Pastuchowa czy Alicja Janowska.

7) Zalety warsztatu naukowego śląskiej badaczki. Odznacza się on wieloma pożądanymi cechami, spośród których na szczególne podkreślenie zasługują trzy: prymat empirii, wyrażający się solidną podstawą źródłowo-materiałową, ostrożność w wyciąganiu wniosków i formułowaniu tez oraz postawa badawcza, charakteryzująca się przekonaniem, że wielu zjawisk językowych nie można wytłumaczyć wyłącznie z punktu widzenia współczesnego języka polskiego. Innymi słowy, między polszczyzną dawną a współczesną istnieją liczne powiązania, a dzisiejszego stanu polszczyzny niepodobna do końca zrozumieć i opisać bez znajomości jej dziejów.

8) Ważne i interesujące wyniki naukowe. Jest ich wiele, zwłaszcza szczegółowych, i każdy czytelnik książki Agnieszki Pieli znajdzie w niej takie, które go zainteresują w sposób szczególny. Trudno natomiast je zebrać recenzentowi, gdyż właściwie każda szczegółowa interpretacja ma walor odkrycia. Dlatego ograniczę się tutaj do wskazania kilku wyników ogólnych:

a) tradycjonalizmy z archaizmem semantycznym są we współczesnym języku polskim liczne, choć nie sposób podać ich dokładnej liczby (s. 160); 
b) dotyczy to w szczególności tradycjonalizmów z archaizmem semantycznym w zasobie zestawień i terminów, a więc w obrębie użyć specjalistycznych (s. 162), choć dzisiaj często, jak w ogóle terminy, przenikają one do słownictwa ogólnego (skarb państwa, mąż zaufania, zamach stanu, udar słoneczny, lusterko wsteczne, most zwodzony, dom zdrojowy itd.);

c) ,, [...] w tradycjonalizmach najliczniej zachowały się trzy rodzaje form archaicznych: fleksyjne, leksykalne i semantyczne. Mniej licznie w polszczyźnie reprezentowane są tradycjonalizmy z unikatem słowotwórczym. Natomiast pozostałe dwa typy tradycjonalizmów, czyli: z archaizmem fonetycznym i składniowym, można uznać w języku ogólnopolskim za rzadkie" (s. 59).

$\mathrm{Na}$ koniec trzeba podkreślić formalne walory rozprawy: sprawną i poprawną polszczyznę w odmianie naukowej (którą autorka, dobra stylistka, włada ze swadą, szczęśliwie łącząc precyzję z jednej, a swobodę z drugiej strony, a także - co już jest jednak, jak sądzę, przynajmniej w równym stopniu zasługą wydawnictwa - nieskazitelną pisownię, interpunkcję i redakcję książki.

Jestem głęboko przekonany, że dzięki wyżej wskazanym zaletom rozprawa Agnieszki Pieli znajdzie poczesne miejsce w trwałym dorobku językoznawstwa polskiego. Ze wszech miar zasadne było więc uznanie jej za dużej miary osiągnięcie badawcze. 